\title{
Asymmetric syntheses of fagomine and its stereoisomers
}

Stephen G. Davies, Ai M. Fletcher,* Paul M. Roberts and James E. Thomson

Department of Chemistry, Chemistry Research Laboratory, University of Oxford, Mansfield Road, Oxford, OX1 3TA, U.K.

e-mail: ai.fletcher@chem.ox.ac.uk

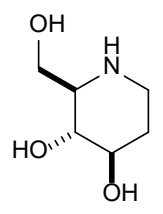

D-fagomine<smiles>OC[C@H]1NCC[C@@H](O)[C@@H]1O</smiles>

L-fagomine<smiles>OCC1NCCC(O)C1O</smiles><smiles>OCC1NCCC(O)C1O</smiles>

D-3-epi-fagomine D-4-epi-fagomine

D-5-epi-fagomine<smiles>OCC1NCCC(O)C1O</smiles>

L-3-epi-fagomine L-4-epi-fagomine<smiles>OCC1NCC[C@H](O)C1O</smiles><smiles>OC[C@H]1NCCC(O)[C@@H]1O</smiles>

L-5-epi-fagomine 


\title{
Asymmetric syntheses of fagomine and its stereoisomers
}

Stephen G. Davies, Ai M. Fletcher,* Paul M. Roberts and James E. Thomson

Department of Chemistry, Chemistry Research Laboratory, University of Oxford, Mansfield Road, Oxford, OX1 3TA, U.K.

e-mail: ai.fletcher@chem.ox.ac.uk

Dedicated to Professor Stephen G. Davies in recognition of his outstanding contributions to the field of organic chemistry.

\begin{abstract}
D-fagomine (1,2,5-trideoxy-1,5-imino-D-arabino-hexitol), a naturally occurring polyhydroxylated piperidine (iminosugar), and its stereoisomers display important biological activities such as glycosidase inhibition. This review delineates both de novo asymmetric and enantiospecific syntheses of fagomine and its stereoisomers.
\end{abstract}

\section{Index:}

1. Introduction

2. Chiral pool syntheses of fagomine and its stereoisomers

2.1. From sugar derivatives

2.2. From other chiral pool starting materials

3. Asymmetric syntheses of fagomine and its stereoisomers via enzymatic approaches

4. de novo Asymmetric syntheses of fagomine and its stereoisomers

5. Conclusion

6. References and notes

\section{Introduction}

Polyhydroxylated piperidines (iminosugars) are widely known as sugar mimics possessing various biological properties. $^{1}$ Among them, arguably the most frequently reported compound in this class is 1deoxynojirimycin $2,{ }^{2,3}$ which has the same relative configuration as glucose $\mathbf{1}$ but the endocyclic oxygen within the pyranose structure is replaced with a nitrogen and the 1-hydroxy group is absent. D-Fagomine 3 
has been reported as a directly related deoxy analogue to 1-deoxynojirimycin 2, i.e., 1,2-dideoxynojirimycin (Figure 1).

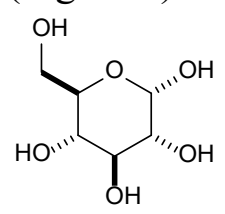

D-glucose 1

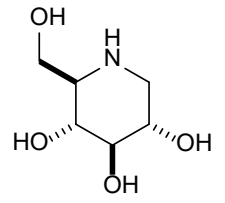

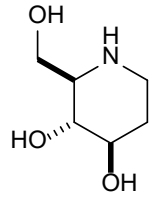

D-fagomine 3

Figure 1. D-Glucose $\mathbf{1}$ and naturally occurring iminosugars $\mathbf{2}$ and $\mathbf{3}$.

D-Fagomine $3\left\{\mathrm{mp} 186-188{ }^{\circ} \mathrm{C} \text {; }[\alpha]_{\mathrm{D}}{ }^{11}+23\left(c 1.0 \text { in } \mathrm{H}_{2} \mathrm{O}\right) ;[\alpha]_{\mathrm{D}}^{11}+37(c 1.0 \text { in } 0.1 \mathrm{M} \text { aq } \mathrm{HCl})\right\}^{4}$ was first isolated from buckwheat seeds in $1974 .{ }^{4}$ Its relative configuration was assigned by NMR analysis and its absolute configuration was established later following the synthesis of an authentic sample $\left\{[\alpha]_{\mathrm{D}}{ }^{20}+21.6(c\right.$ 0.36 in $\left.\left.\mathrm{H}_{2} \mathrm{O}\right)\right\},{ }^{5}$ derived from D-glucose $\mathbf{1}$, which was reported by Fleet and co-workers. ${ }^{5}$ D-Fagomine 3 and glycosides of D-fagomine have been isolated from various natural sources for example the seeds of Castanospermum australe (Leguminosae), ${ }^{6,7}$ the seeds of the African legume Angylocalyx pynaertii, ${ }^{8}$ the seeds of Xanthocericis zambesiaca,${ }^{9}$ the leaves of Morus bombycids, ${ }^{2 a}$ the roots of Lycium Chinese, ${ }^{10}$ the root bark of Morus alba L., ${ }^{2 \mathrm{~d}}$ the pods of Angylocalyx pynaertii, ${ }^{11}$ and from traditional Chinese medicines such as Faeces bombycis ${ }^{12}$ and mulberry leaf (Morus alba L.). ${ }^{13}$ D-Fagomine 3 may be considered to be the parent compound in a set of eight stereoisomers 4-6 and ent-3-ent-6 (Figure 2), which have been systematically named according to carbohydrate nomenclature. Several of these stereoisomers have been isolated from Nature: D-3-epi-fagomine 4 was isolated from the roots of Morus alba, along with D-fagomine $\mathbf{3}$, and its absolute and relative configurations were established by chemical correlation to D-fagomine 3 . $^{2 c, 14}$ Also, D-5-epi-fagomine 6 (also known as D-3,4-di-epi-fagomine) ${ }^{15}$ was isolated along with D-fagomine 3 and D-3-epi-fagomine 4 from the leaves and roots of Xanthocericis zambesiaca. ${ }^{16}$
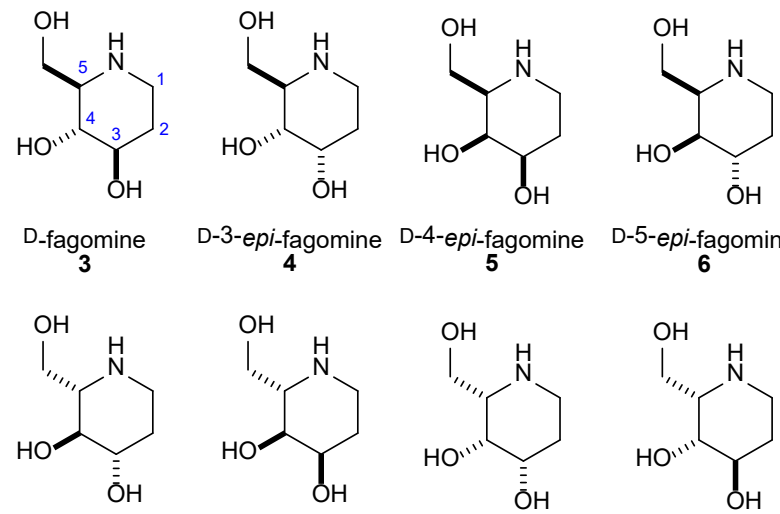

D-5-epi-fagomine

$\underset{\text { Lent }}{\text { L-fagomine }}$
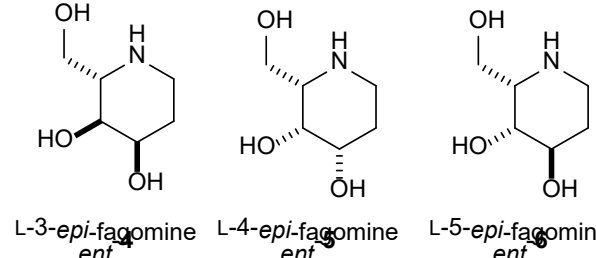

Figure 2. D-Fagomine 3 and its stereoisomers 4-6 and ent-3-ent-6.

Since its first isolation in 1974, many biological studies of D-fagomine 3 and its stereoisomers have been reported. ${ }^{17-19}$ For example, D-fagomine 3 has been shown to possess inhibitory activity against mammalian 
$\alpha$-glucosidase and $\beta$-galactosidase, ${ }^{16,19}$ a potent antihyperglycaemic affect in streptozocin-induced diabetic mice, and also a potentiation of glucose-induced insulin secretion. ${ }^{20,21}$ D-4-epi-Fagomine 5 also displays considerable $\alpha$-galactosidase A inhibitory activity and has been reported to inhibit non-lysosomal glucosylceramidase (GABA-2) which is known to be associated with inflammation and diabetes. ${ }^{18}$ As glycosidases are involved in several important biological processes in vivo, D-fagomine $\mathbf{3}$ and its stereoisomers have been of great interest as therapeutics such as potential treatments for diabetes, inflammation and HIV.

In this review, methods for the syntheses of D-fagomine $\mathbf{3}$ and its stereoisomers will be discussed, highlighting the enantio- and diastereodefining steps in particular.

\section{Chiral pool syntheses of fagomine and its stereoisomers}

\subsection{From sugar derivatives}

Fleet and co-workers confirmed the absolute configuration of D-fagomine $\mathbf{3}$ by completing a synthesis starting from the D-glucose derived azidomannofuranoside $\mathbf{8}^{5}$ Azidodiol $\mathbf{8}$, which was derived from diacetone glucose 7, was realised as a common intermediate for several polyhydroxylated piperidine natural products. ${ }^{22,23}$ Selective tosylation of the primary hydroxy group within $\mathbf{8}$, followed by hydrogenation in the presence of palladium black gave the corresponding amine intermediate, which was treated with $\mathrm{NaOAc}$ in EtOH to promote cyclisation, and subjected to subsequent $N$-protection with $\mathrm{CbzCl}$, which gave the bicyclic product 9 in $72 \%$ yield from 8 . Subsequently, 9 was treated with $\mathrm{Tf}_{2} \mathrm{O}$ and the corresponding triflate was removed by reduction with $\mathrm{LiBHEt}_{3}$ to give $\mathbf{1 0}{ }^{24}$ Acid-mediated hydrolysis of 10, reduction with $\mathrm{NaBH}_{4}$, and subsequent global hydrogenolysis of the $N-\mathrm{Cbz}$ and $O$-Bn protecting groups gave D-fagomine $3\left\{[\alpha]_{\mathrm{D}}{ }^{20}\right.$ $+21.6\left(c 0.36\right.$ in $\left.\left.\mathrm{H}_{2} \mathrm{O}\right)\right\}$ in $28 \%$ yield from 10 (Scheme 1). Comparison of the specific rotation of this sample with that of a sample isolated from a natural source established the absolute configuration of D-fagomine 3. 


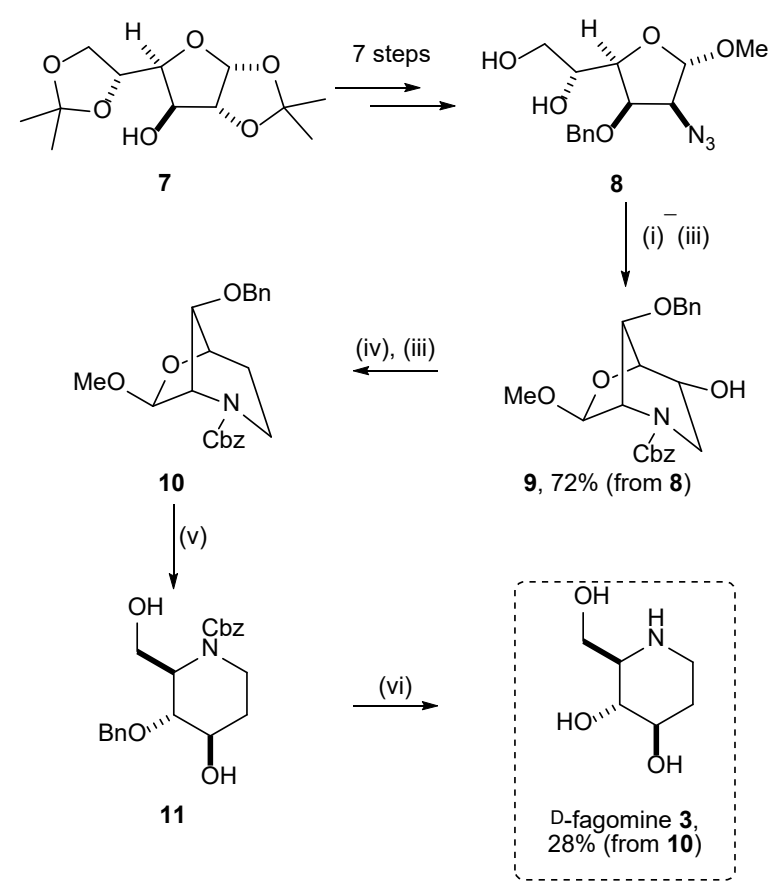

Scheme 1. Reagents and conditions: (i) TsCl, pyridine, rt, 6 h; (ii) $\mathrm{Pd}$ black, $\mathrm{H}_{2}, \mathrm{EtOH}, 30$ min then $\mathrm{NaOAc}, \mathrm{EtOH}, 50{ }^{\circ} \mathrm{C}$; (iii) $\mathrm{CbzCl}, \mathrm{Et}_{2} \mathrm{O}$, aq $\mathrm{NaHCO}_{3}$; (iv) $\mathrm{Tf}_{2} \mathrm{O}$, pyridine, $-20{ }^{\circ} \mathrm{C}$ then $\mathrm{LiBHEt}_{3}, \mathrm{THF}$; (v) $\mathrm{CF}_{3} \mathrm{CO}_{2} \mathrm{H} / \mathrm{H}_{2} \mathrm{O}(1: 1), \mathrm{rt}, 1 \mathrm{~h}$ then $\mathrm{NaBH}$, EtOH, $\mathrm{H}_{2} \mathrm{O}$; (vi) $\mathrm{Pd}(\mathrm{OH})_{2} / \mathrm{C}, \mathrm{H}_{2}, \mathrm{EtOH}$.

Glycals, which incorporate a double bond between $\mathrm{C}(1)$ and $\mathrm{C}(2)$ within the sugar scaffold, have also been employed as chiral pool starting materials for syntheses of members of fagomine family. ${ }^{25-28}$ For example, very recently, Pratap and co-workers reported the stereoselective syntheses of D-fagomine 3 and L-5-epifagomine ent-6 from 3,4,6-tri- $O$-benzyl-D-glucal 12, which is derived from D-glucose. ${ }^{29}$ Hydration of the glycal 12 with $\mathrm{PPh}_{3}$ and $\mathrm{HBr}$ in water and THF gave 13 in $85 \%$ yield. Treatment of 13 with hydroxylamine and $\mathrm{NaOAc}$ in $\mathrm{MeOH}$ gave oxime 14 in $91 \%$ yield, then reduction of oxime 14 with $\mathrm{NaBH}_{4}$ and in situ $\mathrm{N}$ Boc protection gave carbamate $\mathbf{1 5}$ in $74 \%$ yield. The $\mathrm{C}(5)$-epimeric piperidines $\mathbf{1 6}$ and $\mathbf{1 8}$ were prepared from the same intermediate 15: mesylation of the secondary hydroxyl group within $\mathbf{1 5}$ followed by acidmediated $\mathrm{N}$-deprotection and subsequent cyclisation proceeded with inversion of configuration at the $\mathrm{C}(5)$ stereogenic centre to give $\mathbf{1 6}$ in $83 \%$ yield (from 15). Instead, treatment of $\mathbf{1 5}$ under Appel conditions gave iodide 17 in $79 \%$ yield, and analogous cyclisation of 17 gave piperidine 18 in $95 \%$ yield; in this case double inversion of configuration at $\mathrm{C}(5)$ results in overall retention of configuration. Hydrogenolysis of both 16 and 18 gave L-5-epi-fagomine ent-6 $\left\{[\alpha]_{\mathrm{D}}{ }^{25}-10.2\left(c 0.5\right.\right.$ in $\left.\left.\mathrm{H}_{2} \mathrm{O}\right)\right\}$ and D-fagomine $3\left\{[\alpha]_{\mathrm{D}}^{25}+19.7(c 0.5\right.$ in $\left.\left.\mathrm{H}_{2} \mathrm{O}\right)\right\}$ in $76 \%$ and $82 \%$ yield, respectively (Scheme 2). Several other total syntheses of fagomine and its stereoisomers from carbohydrate precursors have also been reported. ${ }^{18,30-33}$ 
$\mathrm{C}_{\mathrm{Bn}}^{\text {(i) }}$

12

$13,85 \%$

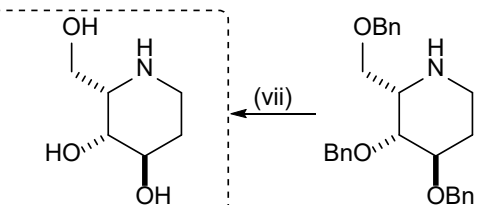

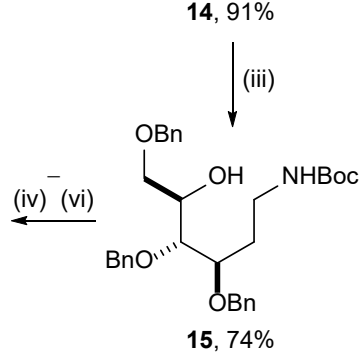

-5-epi-fag8mine

$16,83 \%$ (from 15 )

14, $91 \%$<smiles>COCC1NCCC(O)C1O</smiles>

D-fagmpgine 3

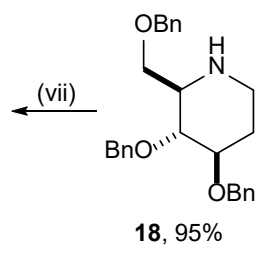<smiles>CC(C)(C)[Mg]O[Na]</smiles>

(v), (vi)

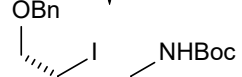

$\mathrm{BnO}$

Scheme 2. Reagents and conditions: (i) $\mathrm{PPh}_{3} \cdot \mathrm{HBr}$, THF, $\mathrm{H}_{2} \mathrm{O}$, rt, 4 h; (ii) $\mathrm{NH}_{2} \mathrm{OH} \cdot \mathrm{HCl}, \mathrm{NaOAc}, \mathrm{MeOH}_{2} \mathrm{H}_{2} \mathrm{O}, \mathrm{rt}, 3 \mathrm{~h}$; (iii) $\mathrm{NaBH}$, $\mathrm{NiCl}_{2} \cdot 6 \mathrm{H}_{2} \mathrm{O}, \mathrm{Boc}_{2} \mathrm{O}, \mathrm{MeOH}, 0{ }^{\circ} \mathrm{C}$ to rt; (iv) $\mathrm{MsCl}, \mathrm{DMAP}, \mathrm{Et}_{3} \mathrm{~N}, \mathrm{CH}_{2} \mathrm{Cl}_{2}, 0{ }^{\circ} \mathrm{C}$ to rt, $2 \mathrm{~h}$; (v) $10 \% \mathrm{HCl}$ in $\mathrm{EtOH}$, rt, $2 \mathrm{~h}$; (vi) $\mathrm{K}_{2} \mathrm{CO}_{3}, \mathrm{MeCN}$, reflux, 4 h; (vii) $10 \% \mathrm{Pd} / \mathrm{C}$, conc aq $\mathrm{HCl}, \mathrm{H}_{2}, \mathrm{MeOH}$, rt, 18 h; (viii) $\mathrm{I}_{2}, \mathrm{PPh}_{3}$, imidazole, PhMe, reflux, 2 h.

\subsection{From other chiral pool starting materials}

Takahata and co-workers reported the syntheses of fagomine and its stereoisomers from a common building block - Garner's aldehyde 19, which is derived from D-serine. ${ }^{34-36}$ Initially, Wittig olefination of Garner's aldehyde 19 gave $\mathbf{2 0}$ in 63\% yield. Acid-mediated hydrolysis of $\mathbf{2 0}$ followed by treatment with TBDPSCl and imidazole gave $\mathbf{2 1}$ in 72\% yield. $N$-Alkylation of $\mathbf{2 1}$ followed by ring-closing metathesis with Grubbs I catalyst gave the key intermediate $\mathbf{2 3}$ in $58 \%$ yield (from 21). Diastereoselective oxidation of $\mathbf{2 3}$ under Upjohn conditions $\left(\mathrm{OsO}_{4}\right.$ and $\left.\mathrm{NMO}\right)$ proceeded on the least hindered face which gave diol $\mathbf{2 4}$ as a single diastereoisomeric product in $92 \%$ yield. Global deprotection of $\mathbf{2 4}$ with $10 \%$ aq $\mathrm{HCl}$ gave D-3-epi-fagomine $4\left\{[\alpha]_{\mathrm{D}}^{26}+74.4\left(c 0.95\right.\right.$ in $\left.\left.\mathrm{H}_{2} \mathrm{O}\right)\right\}$ in $91 \%$ yield (Scheme 3$)$. 


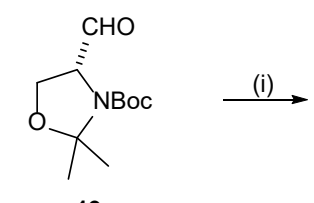

19

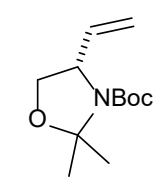

$20,63 \%$

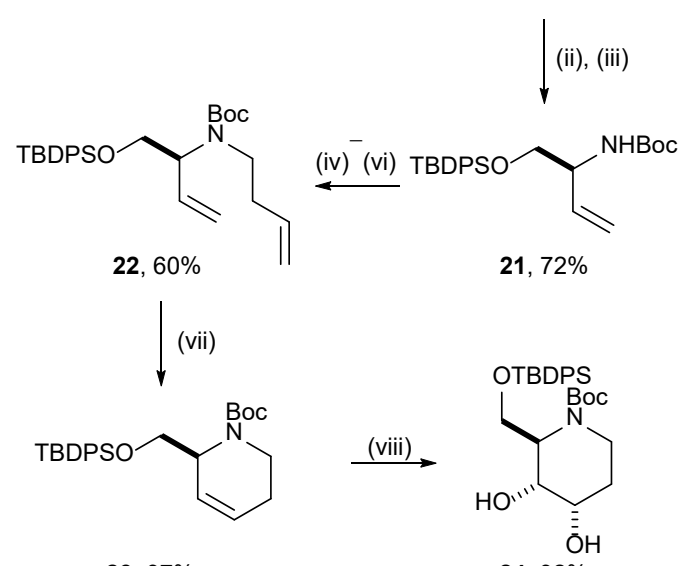

23, $97 \%$

$$
\text { (ix) }
$$

Scheme 3. Reagents and conditions: (i) $\left[\mathrm{MePh}_{3} \mathrm{P}\right]^{+}[\mathrm{I}]^{-}$, NaHMDS, THF, $-20{ }^{\circ} \mathrm{C}$, overnight; (ii) $\mathrm{TsOH}, \mathrm{MeOH}$, rt, overnight; (iii) TBDPSCl, DMAP, imidazole, $\mathrm{CH}_{2} \mathrm{Cl}_{2}$, rt, overnight; (iv) $\mathrm{CF}_{3} \mathrm{CO}_{2} \mathrm{H}, \mathrm{CH}_{2} \mathrm{Cl}_{2}$, rt, $1 \mathrm{~h}$; (v) 4-bromo-1-butene, $\mathrm{K}_{2} \mathrm{CO}_{3}, \mathrm{MeCN}, 9{ }^{\circ} \mathrm{C}$, overnight; (vi) $\mathrm{Boc}_{2} \mathrm{O}, \mathrm{Et}_{3} \mathrm{~N}, \mathrm{CH}_{2} \mathrm{Cl}_{2}$, rt, overnight; (vii) Grubbs I catalyst, $\mathrm{CH}_{2} \mathrm{Cl}_{2}$; (viii) cat. $\mathrm{K}_{2} \mathrm{OsO}_{4} \cdot 2 \mathrm{H}_{2} \mathrm{O}, \mathrm{NMO}$, acetone, $\mathrm{H}_{2} \mathrm{O}$, rt, overnight; (ix) $10 \%$ aq $\mathrm{HCl}, 1,4$-dioxane, $100^{\circ} \mathrm{C}, 30 \mathrm{~min}$.

Ham and co-workers employed the $\operatorname{Pd}(0)$-catalysed stereoselective formation of an oxazine ring from a benzamide in their synthesis of D-fagomine 3 starting from the non-natural, $(R)$-serine derived precursor 25. ${ }^{37}$ Protected $(R)$-serine methyl ester was converted to the corresponding Weinreb amide $\mathbf{2 6}$ in $90 \%$ yield. Treatment of 26 with vinyltin 27 and MeLi followed by diastereoselective reduction with $\mathrm{LiAlH}(\mathrm{OtBu})_{3}$ gave 29 in $60 \%$ yield (from 26). In order to achieve better selectivity in the intramolecular oxazine formation step, it was necessary to protect the hydroxyl group within 29 as the corresponding sterically demanding TBS ether. Treatment of $\mathbf{3 0}$ with $\mathrm{NaH}$ and TBAI in the presence of $\mathrm{Pd}(\mathrm{PPh})_{3}$ gave oxazine 31 in $65 \%$ yield with high diastereoselectivity. Hydroboration of $\mathbf{3 1}$ with 9-BBN followed by oxidation gave primary alcohol 32 in $88 \%$ yield. Mesylation of 32 and subsequent hydrogenolysis facilitated cyclisation to form the corresponding piperidine and a global deprotection with $6 \mathrm{~N} \mathrm{HCl}$ gave D-fagomine $3\left\{[\alpha]_{\mathrm{D}}^{25}+14.9\right.$ (c 0.9 in $\left.\left.\mathrm{H}_{2} \mathrm{O}\right)\right\}$ in 64\% yield over 3 steps (Scheme 4). 


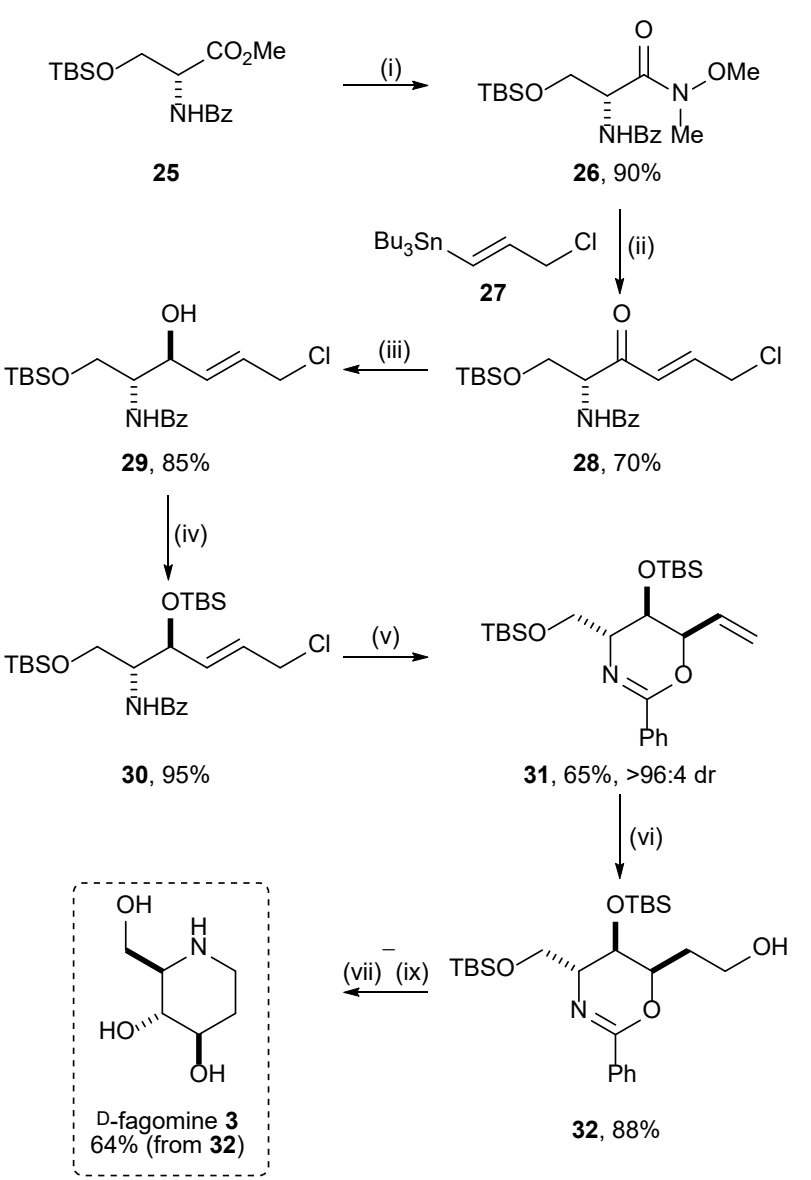

Scheme 4. Reagents and conditions: (i) $\mathrm{NH}(\mathrm{OMe}) \mathrm{Me} \cdot \mathrm{HCl}, \mathrm{Me}_{3} \mathrm{Al}, \mathrm{CH}_{2} \mathrm{Cl}_{2}, \mathrm{rt}, 1 \mathrm{~h}$; (ii) 27, MeLi, THF, $-78{ }^{\circ} \mathrm{C}, 30 \mathrm{~min}$; (iii) $\mathrm{LiAlH}(\mathrm{OtBu})_{3}, \mathrm{EtOH},-78^{\circ} \mathrm{C}, 2 \mathrm{~h}$; (iv) TBSCl, imidazole, DMF, rt, $2 \mathrm{~h}$; (v) $\mathrm{Pd}(\mathrm{PPh})_{3}, \mathrm{NaH}, \mathrm{TBAI}, \mathrm{THF}, 0{ }^{\circ} \mathrm{C}, 5 \mathrm{~h}$; (vi) 9-BBN, THF, rt, 20 h then $\mathrm{H}_{2} \mathrm{O}_{2}, \mathrm{NaOH}, \mathrm{EtOH}, \mathrm{rt}, 30 \mathrm{~min}$; (vii) $\mathrm{MsCl}, \mathrm{Et}_{3} \mathrm{~N}, \mathrm{CH}_{2} \mathrm{Cl}_{2}, 0{ }^{\circ} \mathrm{C}, 2 \mathrm{~h}$; (viii) $\mathrm{Pd}(\mathrm{OH})_{2} / \mathrm{C}, \mathrm{H}_{2}(1 \mathrm{~atm}), \mathrm{MeOH}, \mathrm{rt}$, overnight; (ix) $6 \mathrm{~N} \mathrm{HCl}$ aq, rt, $24 \mathrm{~h}$.

Occhiato and co-workers reported a synthesis of D-fagomine 3 using a Pd-catalysed methoxycarbonylation reaction of a lactam derived vinyl phosphate as the key step, starting from commercially available ethyl $(S)$ 4-chloro-3-hydroxybutanoate $33 .^{38}$ Initially, enantiopure precursor $(S)$-33 was converted to the protected lactam 34 over 5 steps. $^{39}$ Treatment of $\mathbf{3 4}$ with KHMDS followed by the addition of diphenylchlorophosphate gave vinyl phosphate 35 in 85\% yield. Pd-catalysed carbonylation of 35 in the presence of $\mathrm{MeOH}$ gave methyl ester 36 in 95\% yield. Protecting group manipulation then gave $\mathbf{3 7}$ in $74 \%$ yield (from 36). Chemoselective reduction of the ester moiety within 37 with DIBAL-H, and subsequent protection of the resultant primary hydroxyl group with SEMCl gave 38 in 55\% yield (from 37). Regio- and diastereoselective hydroboration of $\mathbf{3 8}$ followed by oxidation gave $\mathbf{3 9}$ in $70 \%$ yield with all three stereogenic centres installed. The global deprotection of $\mathbf{3 9}$ with $\mathrm{HCl}$ gave $\mathrm{D}$-fagomine $\mathbf{3}$ as the corresponding $\mathrm{HCl}$ salt $\left\{[\alpha]_{\mathrm{D}}^{23}+12.3\left(c 0.38\right.\right.$ in $\left.\left.\mathrm{H}_{2} \mathrm{O}\right)\right\}$ in quantitative yield (Scheme 5). 


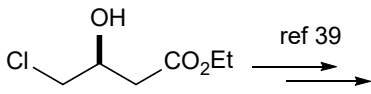

(S)-33

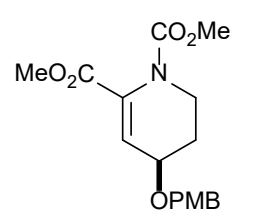<smiles>c1ccccc1</smiles>

$36,95 \%$ (iv), (v)<smiles>COC(=O)C1=CC([OH2+])CCN1C(C)=O</smiles>

37, $74 \%$ (from 36 ) (vi), (vii)<smiles>CC(=O)OCC1=CC([R5](C)(C)C)CCN1C(C)=O</smiles>

38, 55\% (from 37 )

(viii), (ix)

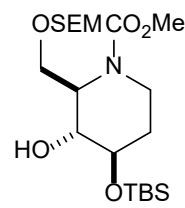

39, $70 \%$ (from 38 )

Scheme 5. Reagents and conditions: (i) KHMDS, THF, $-78{ }^{\circ} \mathrm{C}$; (ii) $(\mathrm{PhO})_{2} \mathrm{P}(\mathrm{O}) \mathrm{Cl}, \mathrm{THF},-78{ }^{\circ} \mathrm{C}$; (iii) $\mathrm{Pd}(\mathrm{OAc})_{2}, \mathrm{PPh}, \mathrm{CO}$, $\mathrm{MeOH}, \mathrm{Et}_{3} \mathrm{~N}, \mathrm{DMF}, 50{ }^{\circ} \mathrm{C}$; (iv) DDQ, $\mathrm{CH}_{2} \mathrm{Cl}_{2} / \mathrm{H}_{2} \mathrm{O}$ (18:1); (v) TBSCl, imidazole, DMF, $40{ }^{\circ} \mathrm{C}$; (vi) DIBAL-H, Et ${ }_{2} \mathrm{O},-78{ }^{\circ} \mathrm{C}$; (vii) $\mathrm{SEMCl}$, DIPEA, $\mathrm{CH}_{2} \mathrm{Cl}_{2}$; (viii) $\mathrm{BH}_{3} \cdot \mathrm{THF},-78{ }^{\circ} \mathrm{C}$ to $0{ }^{\circ} \mathrm{C}$; (ix) $\mathrm{Me}_{3} \mathrm{NO}$, THF, $65{ }^{\circ} \mathrm{C}$; (x) $2 \mathrm{~N} \mathrm{HCl}$, reflux.

\section{Asymmetric syntheses of fagomine and its stereoisomers via enzymatic approaches}

Occhiato and co-workers reported a synthesis of L-fagomine ent-3 via enzymatic kinetic resolution using immobilised lipases from Burkholderia cepacia (lipase PS Amano IM). ${ }^{40}$ Racemic allylic alcohol 41 was prepared from lactam $\mathbf{4 0}$ over four steps in 57\% yield. Kinetic resolution of $\mathbf{4 1}$ under optimised conditions using lipase PS Amano IM and vinyl acetate gave (S)-alcohol 42 (93\% ee) and acetate $(R)-\mathbf{4 3}(96 \%$ ee). After O-protection of $\mathbf{4 2}$ with TIPSCl, reduction of the corresponding $\alpha, \beta$-unsaturated ester with DIBAL-H gave alcohol 44 in $66 \%$ yield. Treatment of 44 with SEMCl gave 45 in $77 \%$ yield and diastereoselective hydroboration followed by oxidative work-up gave 46 in $72 \%$ yield. Subsequent acid-mediated global hydrolysis gave L-fagomine ent-3 as the corresponding $\mathrm{HCl}$ salt $\left\{[\alpha]_{\mathrm{D}}^{21}-12.0\left(c 0.26\right.\right.$ in $\left.\left.\mathrm{H}_{2} \mathrm{O}\right)\right\}$ in quantitative yield. Similarly, enantioenriched acetate $\mathbf{4 3}$ was converted into ent-42 via basic ester hydrolysis in a formal synthesis of D-fagomine $3^{38}$ (Scheme 6). Takahata also demonstrated preparations of both 
enantiomeric series of fagomines and their diastereoisomers from a common building block using the lipasecatalysed transesterification. ${ }^{41}$<smiles>CC(=O)N1CCCC(=O)C1</smiles><smiles>CC(=O)OC1C=C(C(C)=O)N(C(C)=O)CC1</smiles>

41

(S)-42, 45\%, 93\% ee $\quad(R)-43,42 \%, 96 \%$ ee

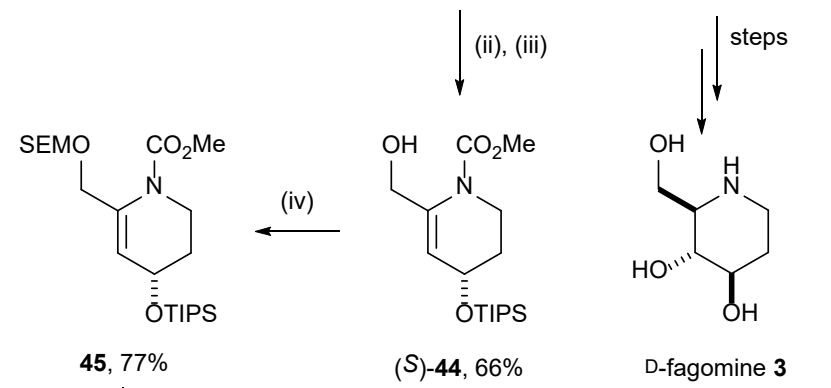

(v), (vi)

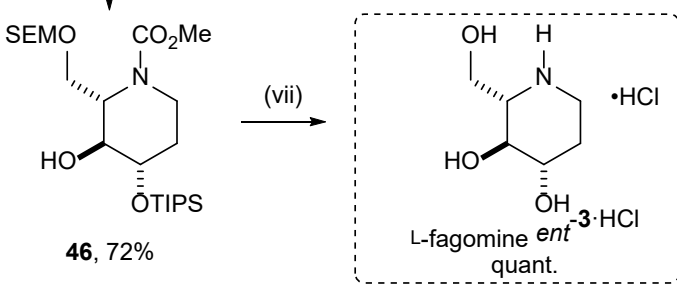

Scheme 6. Reagents and conditions: (i) Lipase PS “AMANO" IM, vinyl acetate, THF, $30^{\circ} \mathrm{C}, 9 \mathrm{~h}$; (ii) TIPSCl, imidazole, DMF, $40{ }^{\circ} \mathrm{C}, 5 \mathrm{~h}$; (iii) DIBAL-H, Et $\mathrm{O}_{2} \mathrm{O},-78{ }^{\circ} \mathrm{C}, 1 \mathrm{~h}$ then $0{ }^{\circ} \mathrm{C}, 30 \mathrm{~min}$; (iv) SEMCl, DIPEA, $\mathrm{CH}_{2} \mathrm{Cl}_{2}, 30^{\circ} \mathrm{C}, 16 \mathrm{~h}$; (v) $\mathrm{BH}_{3} \cdot \mathrm{THF}, \mathrm{THF}, 0$ ${ }^{\circ} \mathrm{C}, 20 \mathrm{~h}$; (vi) $\mathrm{Me}_{3} \mathrm{NO}, 65^{\circ} \mathrm{C}, 2 \mathrm{~h}$; (vii) $2 \mathrm{~N}$ aq HCl, reflux, $18 \mathrm{~h}$.

Babich and co-workers developed a one-pot cascade enzymatic reaction for the synthesis of enantio- and diastereoisomerically pure natural and non-natural carbohydrates from glycerol and aldehydes. This fourenzymatic cascade reaction was highlighted in the asymmetric synthesis of D-fagomine $3{ }^{42}$ The cascade reaction of glycerol 47 and $N$-Alloc protected aldehyde 48 gave aldol product 49 in 69\% yield and $>93: 7 \mathrm{dr}$. Treatment of 49 with $\mathrm{Pd} / \mathrm{C}$ and $\mathrm{Et}_{3} \mathrm{SiH}$ promoted deprotection of the $\mathrm{N}$-Alloc group followed by in situ reductive cyclisation to give D-fagomine $3\left\{[\alpha]_{\mathrm{D}}{ }^{20}+6.6(c 0.6\right.$ in $\left.\mathrm{MeOH})\right\}$ in quantitative yield (Scheme 7). Several other groups have also reported asymmetric syntheses of fagomine and its stereoisomers via enzymatic approaches (aldolases, in particular, have often been used). ${ }^{43}$ 


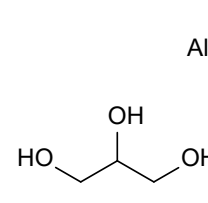

47

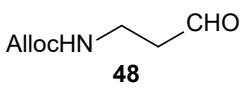
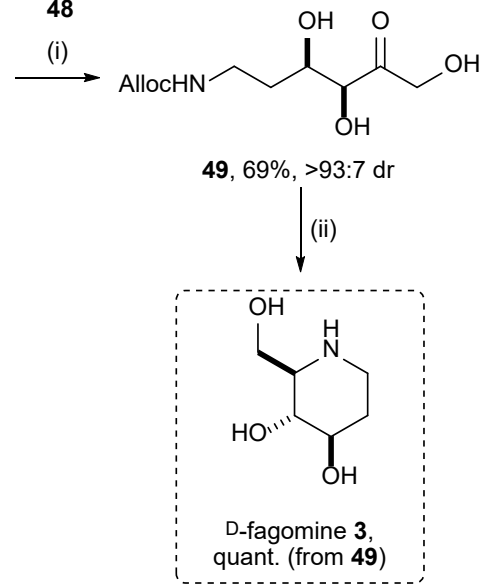

Scheme 7. Reagents and conditions: (i) $\mathrm{PPi}$, GPO, catalase, RAMA, PhoN-Sf, $\mathrm{H}_{2} \mathrm{O}, 20{ }^{\circ} \mathrm{C}, 12 \mathrm{~h}$; (ii) $\mathrm{Et}_{3} \mathrm{SiH}, \mathrm{Pd} / \mathrm{C}, \mathrm{EtOH}, \mathrm{rt}$, overnight.

\section{4. de novo Asymmetric syntheses of fagomine and its stereoisomers}

Ferjancic and co-workers reported a short asymmetric synthesis of L-4-epi-fagomine ent-5 using an $(S)$ proline catalysed aldol reaction as a key step. ${ }^{44}$ Treatment of commercially available protected amine $\mathbf{5 0}$ with acrolein $\mathbf{5 1}$ gave $\beta$-amino aldehyde $\mathbf{5 2}$ in $41 \%$ yield. The $(S)$-proline catalysed aldol reaction of $\mathbf{5 4}$ with dioxanone $\mathbf{5 3}$ gave the adduct $\mathbf{5 4}$ in $60 \%$ yield as a single diastereoisomer. The global $\mathrm{N}$-deprotection of $\mathbf{5 4}$ followed by diastereoselective reductive cyclisation via hydrogenolysis and hydrogenation afforded piperidine $\mathbf{5 5}$ in $\mathbf{7 8 \%}$ yield. Acid-mediated hydrolysis of $\mathbf{5 5}$ gave L-4-epi-fagomine ent-5 $\left\{[\alpha]_{\mathrm{D}}{ }^{20}-15.5(c\right.$ 1.0 in $\mathrm{H}_{2} \mathrm{O}$ ) $\}$ in $92 \%$ yield (Scheme 8).

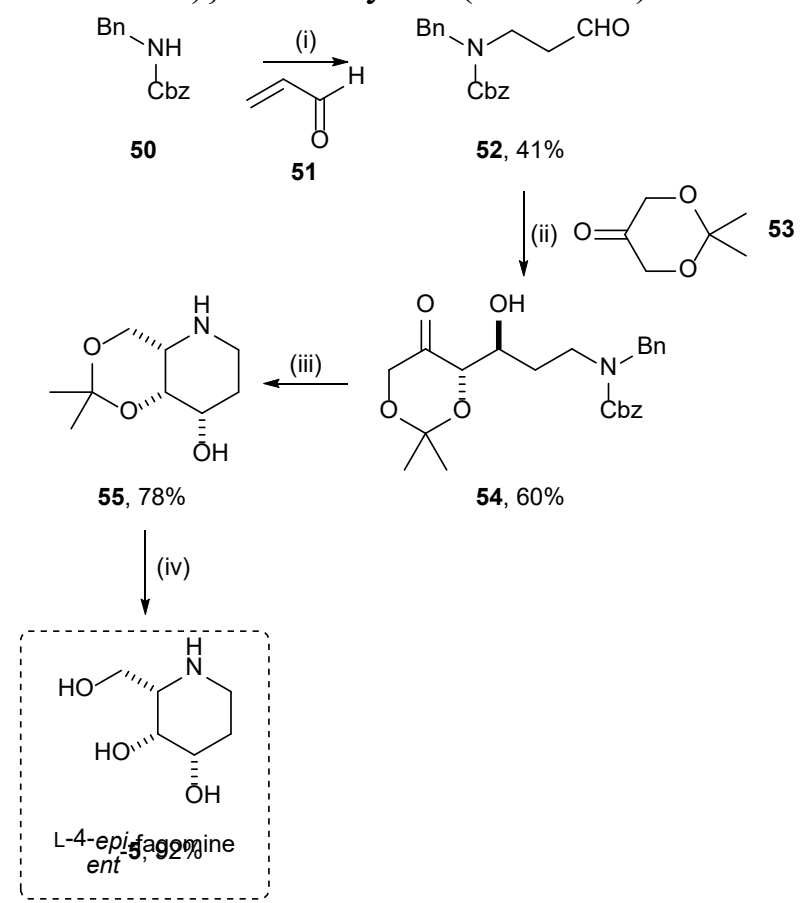

Scheme 8. Reagents and conditions: (i) acrolein 51, (+)-camphorsulfonic acid (CSA), $\mathrm{CH}_{2} \mathrm{Cl}_{2}, 0{ }^{\circ} \mathrm{C}$ to rt, $3.5 \mathrm{~h}$; (ii) 53, (S)-proline, DMF, $4{ }^{\circ} \mathrm{C}, 24$ h; (iii) $\mathrm{H}_{2}$ (5 atm), $\mathrm{Pd} / \mathrm{C}, \mathrm{EtOH}, 2$ h; (iv) $3 \mathrm{M} \mathrm{HCl}, \mathrm{MeOH}$, reflux, 4 h.

The vicinal diol unit within fagomine and its epimers may also be installed via Sharpless asymmetric dihydroxylation. Hirai and co-workers reported the asymmetric synthesis of D-fagomine $\mathbf{3}$ via Sharpless 
asymmetric dihydroxylation and $\mathrm{Pd}(\mathrm{II})$-catalysed cyclisation to form the piperidine ring. ${ }^{45} \mathrm{~N}$-Boc protected 3-aminopropanol 56 was oxidised under Swern conditions and subsequent Horner-Wadsworth-Emmons reaction of the resultant aldehyde was followed by reduction with DIBAL-H to give the corresponding allylic alcohol, which was $O$-TBS protected to give 57 in $74 \%$ yield (from 56). Sharpless asymmetric dihydroxylation of $\mathbf{5 7}$ gave the corresponding syn-diol, which was protected as the corresponding bisbenzyl ether. Its acid promoted desilylation gave primary alcohol $\mathbf{5 8}$ in 29\% yield (from 57). The same sequential treatment of 58 (i.e., Swern oxidation, Horner-Wadsworth-Emmons reaction and reduction with DIBAL-H) afforded homologated allylic alcohol 59 in $40 \%$ yield (from 58). Treatment of 59 with $\mathrm{PdCl}_{2}\left(\mathrm{MeCN}_{2}\right.$ facilitated diastereoselective cyclisation to give vinyl piperidine $\mathbf{6 0}$ in $90 \%$ yield. Ozonolysis of the vinyl group within 60 followed by reductive work-up, acid-mediated deprotection of the $N$-Boc group, and hydrogenolysis gave D-fagomine $3\left\{[\alpha]_{D^{27}}+13.4\left(c 0.86\right.\right.$ in $\left.\left.\mathrm{H}_{2} \mathrm{O}\right)\right\}$ in $45 \%$ yield over 3 steps from 60 (Scheme 9).

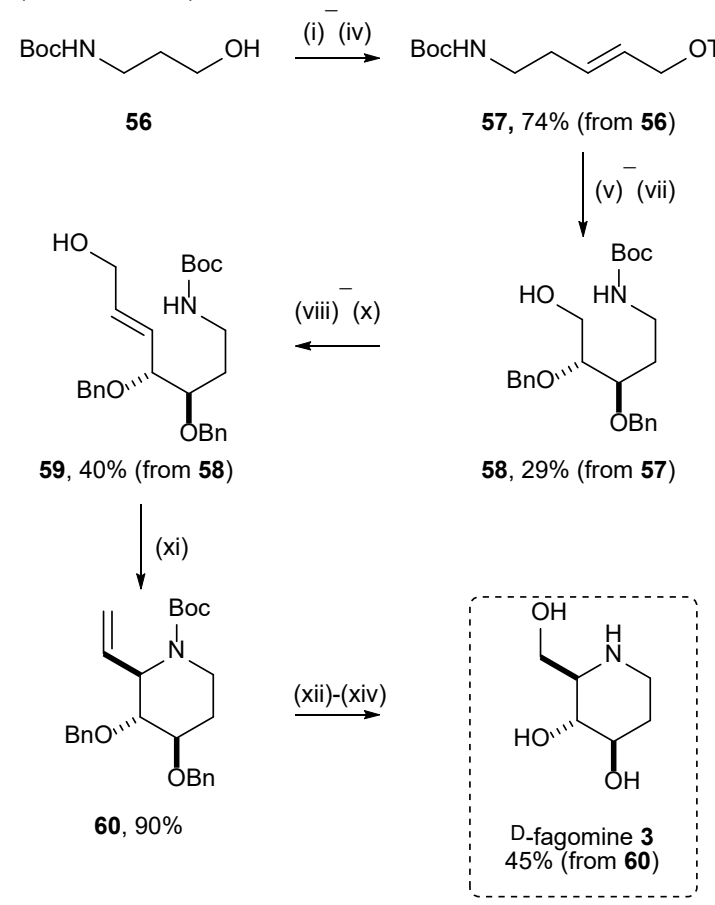

Scheme 9. Reagents and conditions: (i) $(\mathrm{COCl})_{2}, \mathrm{DMSO}, \mathrm{Et}_{3} \mathrm{~N}, \mathrm{CH}_{2} \mathrm{Cl}_{2},-78{ }^{\circ} \mathrm{C}, 1.5 \mathrm{~h}$; (ii) (EtO) ${ }_{2} \mathrm{P}(\mathrm{O}) \mathrm{CH}_{2} \mathrm{CO} \mathrm{Et}_{2}, \mathrm{NaH}, \mathrm{THF}$, $-50{ }^{\circ} \mathrm{C}$ to rt, $1 \mathrm{~h}$; (iii) DIBAL-H, THF, $-78{ }^{\circ} \mathrm{C}, 2 \mathrm{~h}$; (iv) TBSCl, imidazole, DMF, rt, $3 \mathrm{~h}$; (v) AD-mix- $\beta, \mathrm{CH}_{3} \mathrm{SO}_{2} \mathrm{NH}_{2}, \mathrm{tBuOH}^{-\mathrm{H}_{2} \mathrm{O}}$ (1:1), $0{ }^{\circ} \mathrm{C}, 20$ h; (vi) BnBr, NaH, Bu $4 \mathrm{NI}, \mathrm{THF}, \mathrm{rt}, 4 \mathrm{~h}$; (vii) $p$-TsOH, MeOH, rt, 3 h; (viii) IBX, THF/DMSO (1:1), rt, 4 h; (ix) (EtO) $)_{2} \mathrm{P}(\mathrm{O}) \mathrm{CH}_{2} \mathrm{CO}_{2} \mathrm{Et}$, NaH, THF, rt, $30 \mathrm{~min}$; (x) DIBAL-H, THF, $-78{ }^{\circ} \mathrm{C}$ to rt, $5 \mathrm{~h}$; (xi) $\mathrm{PdCl}_{2}\left(\mathrm{MeCN}_{2}, \mathrm{THF}, \mathrm{rt}, 3 \mathrm{~h}\right.$; (xii) $\mathrm{O}_{3}$, $\mathrm{CH}_{2} \mathrm{Cl}_{2} / \mathrm{MeOH}(4: 1),-78{ }^{\circ} \mathrm{C}$ then $\mathrm{NaBH}_{4},-78{ }^{\circ} \mathrm{C}$ to rt, $2 \mathrm{~h}$; (xiii) aq $\mathrm{HCl}, \mathrm{MeOH}, 70{ }^{\circ} \mathrm{C}, 5 \mathrm{~h}$; (xiv) $\mathrm{H}_{2}(1 \mathrm{~atm}), \mathrm{Pd} / \mathrm{C}, \mathrm{AcOH}, \mathrm{rt}, 2$ days.

Bates and co-workers reported the asymmetric synthesis of L-5-epi-fagomine ent-6 via asymmetric dihydroxylation to introduce the vicinal diol unit and gold(I)-catalysed allene cyclisation. ${ }^{46}$ Alkyne $\mathbf{6 1}$ was treated with $\mathrm{NBS}$ and $\mathrm{AgNO}_{3}$ to give the corresponding terminal bromide, which was reduced with $\mathrm{AlCl}_{3}$ and $\mathrm{LiAlH}_{4}$ to give $(E)$-vinyl bromide 62 in $66 \%$ yield (from 61). Sonogashira coupling of 62 with trimethylsilylacetylene followed by introduction of the PMP ether via Mitsunobu reaction gave $\mathbf{6 3}$ in $44 \%$ 
yield (from 62). Asymmetric dihydroxylation of 63 with AD-mix- $\beta$ afforded $s y n$-diol 64 in $86 \%$ yield and 97\% ee. Treatment of 64 with $\mathrm{K}_{2} \mathrm{CO}_{3}$ in $\mathrm{MeOH}$ followed by Searles-Crabbé homologation ${ }^{47}$ and $O$-silyl protection of the diol unit gave allene $\mathbf{6 5}$ in $65 \%$ yield (from 64$)$. The requisite $(N$-Boc protected) amino functionality was installed via five further synthetic transformations to give $\mathbf{6 6}$ in 52\% overall yield from 65 . Gold (I) catalysed diastereoselective cyclisation of 66 gave piperidine 67 in $85 \%$ yield as a single diastereoisomer. Ozonolysis of $\mathbf{6 7}$ followed by reductive work-up and subsequent acid mediated global deprotection gave L-5-epi-fagomine ent-6 $\left\{[\alpha]_{\mathrm{D}}{ }^{21}-10.6\left(c 0.32\right.\right.$ in $\left.\left.\mathrm{H}_{2} \mathrm{O}\right)\right\}$ in 53\% yield from 67 (Scheme 10).

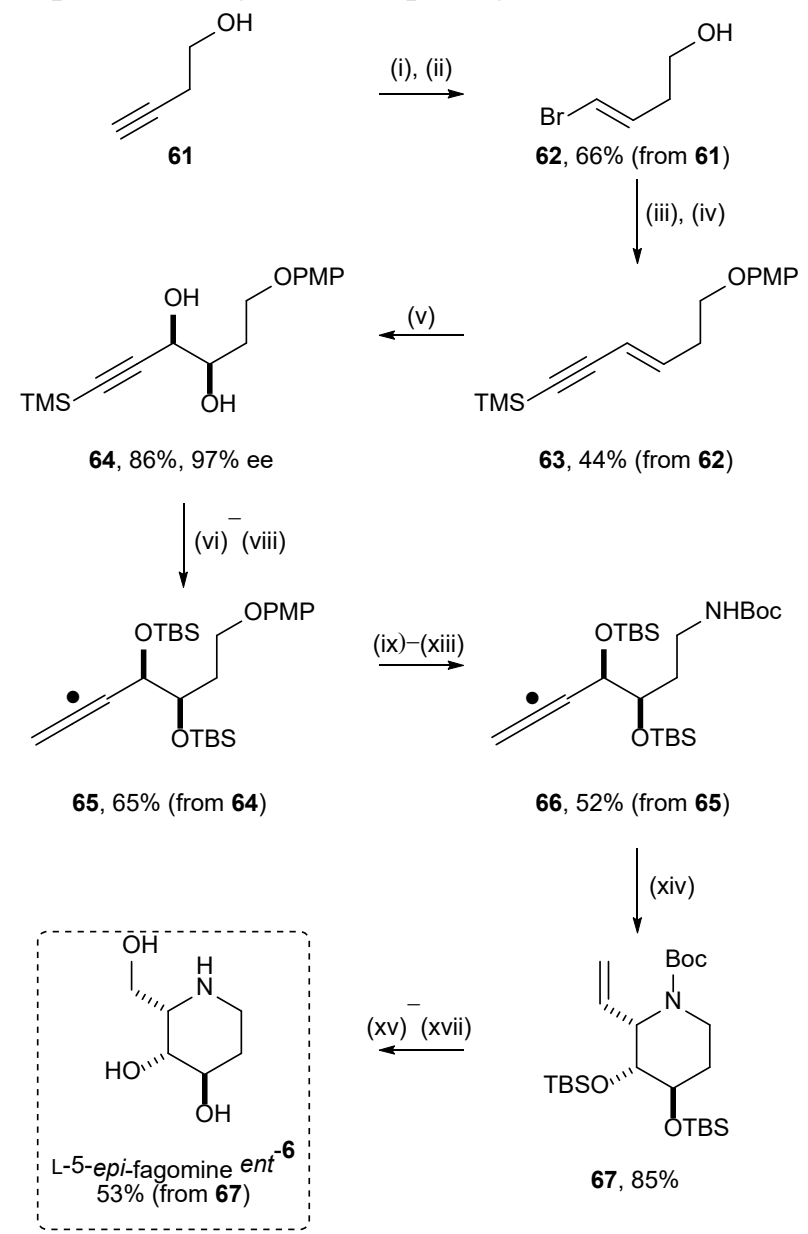

Scheme 10. Reagents and conditions: (i) $\mathrm{NBS}, \mathrm{AgNO}_{3}$; (ii) $\mathrm{AlCl}_{3}, \mathrm{LiAlH}_{4}$; (iii) $\mathrm{HC} \equiv \mathrm{CTMS},\left(\mathrm{Ph}_{3} \mathrm{P}\right)_{2} \mathrm{PdCl}_{2}, \mathrm{CuI}, \mathrm{Et} \mathrm{t}_{3} \mathrm{~N}$, THF; (iv) $p$-(MeO) $\mathrm{C}_{6} \mathrm{H}_{4} \mathrm{OH}, \mathrm{PPh}_{3}$, DIAD; (v) AD mix- $\beta, \mathrm{MeSO}_{2} \mathrm{NH}_{2}$, aq ${ }^{\mathrm{t}} \mathrm{BuOH}$; (vi) $\mathrm{MeOH}, \mathrm{K}_{2} \mathrm{CO}_{3}$; (vii) $\left(\mathrm{CH}_{2} \mathrm{O}\right)_{\mathrm{n}}, \mathrm{Cy}_{2} \mathrm{NH}, \mathrm{CuBr}$; (viii) TBSOTf, 2,6-lutidine; (ix) CAN, pyridine, aq MeCN; (x) $\mathrm{MsCl}$, Et $t_{3} \mathrm{~N}$; (xi) $\mathrm{NaN}_{3}$; (xii) $\mathrm{PPh}_{3}, \mathrm{H}_{2} \mathrm{O}$; (xiii) $\mathrm{Boc}_{2} \mathrm{O},{ }^{i} \operatorname{Pr}_{2} \mathrm{NEt}$; (xiv) $\mathrm{Ph}_{3} \mathrm{PAuCl}, \mathrm{AgSbF}_{6}, \mathrm{CaCO}_{3}$; (xv) $\mathrm{O}_{3}, \mathrm{NaBH}_{4}$; (xvi) $\mathrm{HCl}, \mathrm{MeOH}$, dioxane; (xvii) amberlyst A26.

Ghosh and co-workers reported the asymmetric syntheses of D-fagomine 3 and D-5-epi-fagomine 6 from C2-symmetric 3,4-bis-silyl substituted adipic acid derivatives (which incorporate the Evans chiral auxiliary) via diastereoselective azidation as the key step. ${ }^{15}$ Mg-mediated reductive coupling of silicon-tethered diacrylic acid derivative $\mathbf{6 8}$ gave, after exhaustive purifications, 69 and $\mathbf{7 0}$ in $27 \%$ and $38 \%$ yield, respectively as single diastereoisomers. ${ }^{48}$ The major diastereoisomer $\mathbf{7 0}$ was treated with KHMDS followed by addition of trisyl azide to give $\mathbf{7 1}$ in $74 \%$ yield as a single diastereoisomer. The stereochemical outcome of this reaction was consistent with the Evans chiral auxiliary being the dominant stereocontrol element in 
this system. Azide 71 was reduced and protected in situ to give $\mathbf{7 2}$ in $96 \%$ yield. The oxazolidinones were removed by treatment with $\mathrm{K}_{2} \mathrm{CO}_{3}$ in $\mathrm{MeOH}$, and treatment of the corresponding dicarboxylic acid with diazomethane gave 73 in $86 \%$ yield. Treatment of 73 with $\mathrm{CF}_{3} \mathrm{CO}_{2} \mathrm{H}$ removed the $N$-Boc group and cyclisation gave lactam 74 in $67 \%$ yield. Reduction of 74 with $\mathrm{LiAlH}_{4}$ and Tamao-Fleming oxidation gave D-5-epi-fagomine $\left\{[\alpha]_{\mathrm{D}}{ }^{24}+12.1\left(c \quad 0.33\right.\right.$ in $\left.\left.\mathrm{H}_{2} \mathrm{O}\right)\right\}$ in $65 \%$ yield (from 74 ). The analogous sequential treatment of the other diastereoisomer 69 gave D-fagomine $3\left\{[\alpha]_{\mathrm{D}}^{22}+18.6\left(c 0.43\right.\right.$ in $\left.\left.\mathrm{H}_{2} \mathrm{O}\right)\right\}$ in $40 \%$ overall yield (Scheme 11). ${ }^{15}$

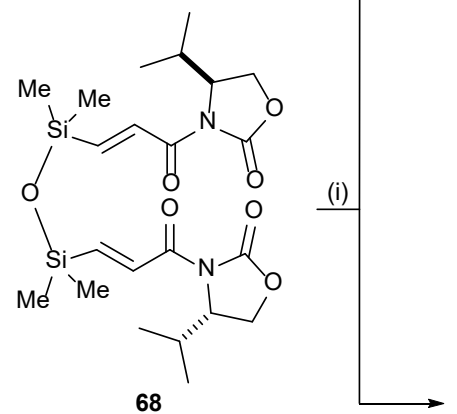

68

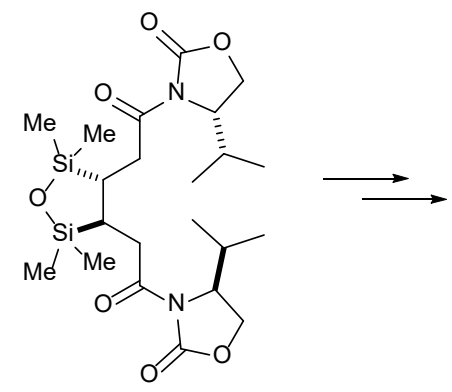

$69,27 \%$<smiles>CC(C)C1COC(=O)N1C(=O)CC1[C@H](CC(=O)N2C(=O)OC[C@H]2C(C)C)[Si](C)(C)O[Si]1(C)C</smiles>

70, $38 \%$

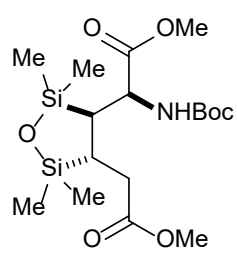

$73,86 \%$

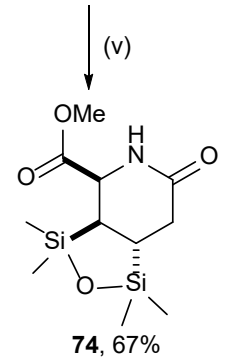

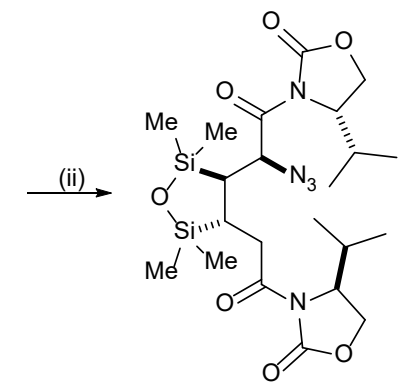

71, $74 \%$

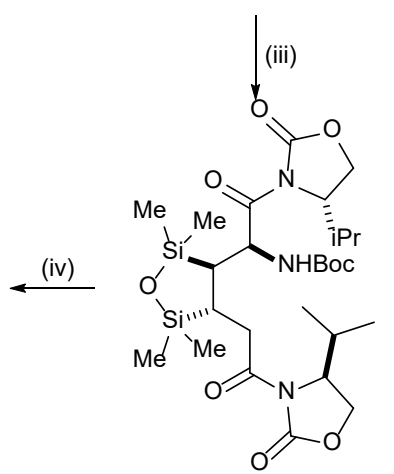

72, $96 \%$

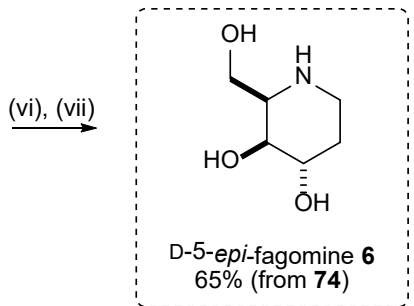

Scheme 11. Reagents and conditions: (i) $\mathrm{Mg}$, TMSCl, DMF, $0{ }^{\circ} \mathrm{C}$ to $\mathrm{rt}, 6 \mathrm{~h}$; (ii) $\mathrm{KHMDS}, \mathrm{THF},-78{ }^{\circ} \mathrm{C}, 30 \mathrm{~min}$ then trisyl azide, $-78{ }^{\circ} \mathrm{C}, 8 \mathrm{~min}$ then $\mathrm{AcOH},-78{ }^{\circ} \mathrm{C}$; (iii) $\mathrm{H}_{2}$ (1 atm), $\mathrm{Pd} / \mathrm{C}$, (Boc) $)_{2} \mathrm{O}$, EtOAc, rt, $24 \mathrm{~h}$; (iv) $\mathrm{K}_{2} \mathrm{CO}_{3}, \mathrm{MeOH}^{\circ} 3{ }^{\circ} \mathrm{C}, 1 \mathrm{~h}$ then $\mathrm{HCl}$, 
$\mathrm{H}_{2} \mathrm{O}$, rt then $\mathrm{CH}_{2} \mathrm{~N}_{2}, \mathrm{Et}_{2} \mathrm{O}$; (v) $\mathrm{CF}_{3} \mathrm{CO}_{2} \mathrm{H}, \mathrm{CH}_{2} \mathrm{Cl}_{2}, 30{ }^{\circ} \mathrm{C}, 1 \mathrm{~h}$ then aq $\mathrm{NaHCO}_{3}$; (vi) $\mathrm{LiAlH}_{4}, \mathrm{Et}_{2} \mathrm{O}$, reflux, $4 \mathrm{~h}$; (vii) $\mathrm{KHF}_{2}, \mathrm{H}_{2} \mathrm{O}_{2}$, $\mathrm{THF} / \mathrm{MeOH}(1: 1), 60^{\circ} \mathrm{C}, 15 \mathrm{~h}$.

Davies and co-workers have recently reported a diastereodivergent route to L-fagomine ent-3, L-3-epifagomine ent-4 and L-5-epi-fagomine ent-6 employing diastereoselective syn- and anti-dihydroxylations of an enantiopure tetrahydropyridine precursor. ${ }^{49,50}$ Conjugate addition of lithium $(R)-N$-(but-3-en-1-yl)- $N-(\alpha-$ methylbenzyl) amide (R)-76 to dienyl ester 75 (derived from sorbic acid), followed by in situ enolate oxidation with (-)-camphorsulfonyloxaziridine [(-)-CSO] gave $\alpha$-hydroxy- $\beta$-amino ester 77 in $64 \%$ yield as a single diastereoisomer. Reduction of $\mathbf{7 7}$ with $\mathrm{LiAlH}_{4}$ gave diol $\mathbf{7 8}$ in $89 \%$ yield, and subsequent oxidative cleavage of the diol moiety within 78 with $\mathrm{NaIO}_{4}$ followed by reduction with $\mathrm{NaBH}_{4}$ gave 79 in $81 \%$ yield. Ring-closing metathesis of $\mathbf{7 9}$ with Grubbs II catalyst gave tetrahydropyridine $\mathbf{8 0}$ in $75 \%$ yield. Tetrahydropyridine $\mathbf{8 0}$ was next subjected to syn- and anti-dihydroxylation conditions. syn-Dihydroxylation of $\mathbf{8 0}$ under Upjohn conditions gave triol $\mathbf{8 1}$ in 45\% yield and $>95: 5 \mathrm{dr}$. After hydrogenolysis of 81, L-3-epifagomine ent-4 $\left\{[\alpha]_{\mathrm{D}}{ }^{20}-72.2\left(c 1.0\right.\right.$ in $\left.\left.\mathrm{H}_{2} \mathrm{O}\right)\right\}$ was isolated in quantitative yield as a single diastereoisomer. Chemoselective olefinic oxidation ${ }^{51}$ of $\mathbf{8 0}$ with $m \mathrm{CPBA}$ and aq $\mathrm{HBF}_{4}$ gave a 41:59 mixture of anti-diols $\mathbf{8 2}$ and 83, respectively. After separation hydrogenolytic $N$-deprotection of $\mathbf{8 2}$ and $\mathbf{8 3}$ gave L-fagomine ent-3 $\left\{[\alpha]_{\mathrm{D}}^{20}-15.0\left(c 0.5\right.\right.$ in $\left.\left.\mathrm{H}_{2} \mathrm{O}\right)\right\}$ and L-5-epi-fagomine ent-6 $\left\{[\alpha]_{\mathrm{D}}{ }^{20}-13.6\left(c 0.5\right.\right.$ in $\left.\left.\mathrm{H}_{2} \mathrm{O}\right)\right\}$, respectively, in quantitative yield in each case (Scheme 12). 

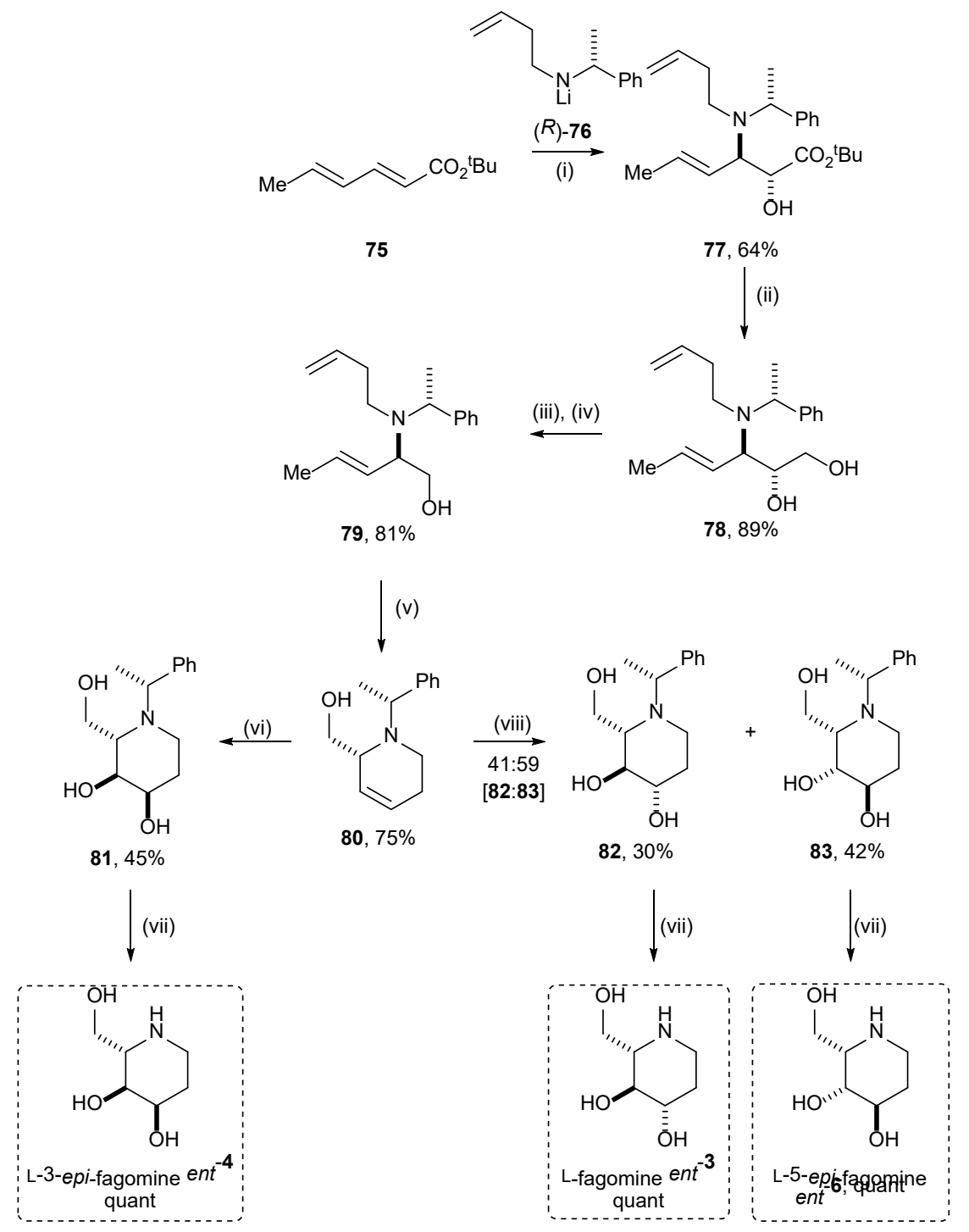

Scheme 12. Reagents and conditions: (i) (R)-76, THF, $-78{ }^{\circ} \mathrm{C}, 2 \mathrm{~h}$ then $(-)-\mathrm{CSO},-78{ }^{\circ} \mathrm{C}$ to $\mathrm{rt}, 12 \mathrm{~h}$; (ii) $\mathrm{LiAlH}_{4}, \mathrm{THF},-78^{\circ} \mathrm{C}$ to rt, 16 h; (iii) $\mathrm{NaIO}_{4}, \mathrm{EtOH} / \mathrm{H}_{2} \mathrm{O}$ (5:1), rt, 20 min; (iv) $\mathrm{NaBH}_{4}, 0{ }^{\circ} \mathrm{C}$ to rt, $12 \mathrm{~h}$; (v) Grubbs $\mathrm{II}, \mathrm{CH}_{2} \mathrm{Cl}_{2}, 35^{\circ} \mathrm{C}, 48$ h; (vi) OsO NMO, THF/ $\mathrm{H}_{2} \mathrm{O}$ (4:1), rt, $12 \mathrm{~h}$; (vii) $\mathrm{H}_{2}(1 \mathrm{~atm}), \mathrm{Pd}(\mathrm{OH})_{2} / \mathrm{C}, \mathrm{MeOH}$, rt, $12 \mathrm{~h}$; (viii) $m \mathrm{CPBA}$, aq $\mathrm{HBF}_{4}, \mathrm{CH}_{2} \mathrm{Cl}_{2}$, rt, $48 \mathrm{~h}$.

Davies and co-workers also demonstrated syntheses of D-fagomine $\mathbf{3}$ and all three other D-configured diastereoisomers 4-6 via diastereoselective aminohydroxylation methodology to install the $\mathrm{C}(4) H$ and $\mathrm{C}(5) H$ stereogenic centres and aldol reactions with ethyl acetate to install the $\mathrm{C}(3) H$ stereogenic centre of the corresponding diastereoisomeric fagomine diastereoisomers. ${ }^{52}$ Aminohydroxylation of 84 with $(R)-85$ and (-)-CSO gave anti- $\alpha$-hydroxy- $\beta$-amino ester 86 in $77 \%$ yield as a single diastereoisomer. The hydroxyl group within 85 was protected as the corresponding benzyl ether, and reduction with DIBAL-H gave primary alcohol $\mathbf{8 7}$ in $87 \%$ yield (from 86 ). Swern oxidation of $\mathbf{8 7}$ followed by aldol reaction of the resultant aldehyde $\mathbf{8 8}$ with the lithium enolate derived from ethyl acetate gave a 65:35 mixture of $\mathbf{8 9}$ and $\mathbf{9 0}$, respectively, which were isolated in 39\% and 33\% yield. The major diastereoisomeric product 89 was treated with $\mathrm{H}_{2}$ in the presence of $\mathrm{Pd}(\mathrm{OH})_{2} / \mathrm{C}$ in $\mathrm{MeOH}$ to give lactam 91 . Treatment of 91 with $\mathrm{Na}$ and naphthalene in DME removed the $O$-benzyl group, subsequent reduction of the lactam with $\mathrm{BH}_{3}$, and acid mediated deprotection of the O-silyl group gave D-fagomine $3\left\{[\alpha]_{\mathrm{D}}{ }^{25}+14.9\left(c 1.0\right.\right.$ in $\left.\left.\mathrm{H}_{2} \mathrm{O}\right)\right\}$ in $36 \%$ yield 
from 89. Analogous sequential transformation of the minor diastereoisomeric aldol product 90 gave $\mathrm{D}-3$-epifagomine $4\left\{[\alpha]_{\mathrm{D}}^{25}+62.8\left(c 1.0\right.\right.$ in $\left.\left.\mathrm{H}_{2} \mathrm{O}\right)\right\}$ in $40 \%$ yield from 90 (Scheme 13).

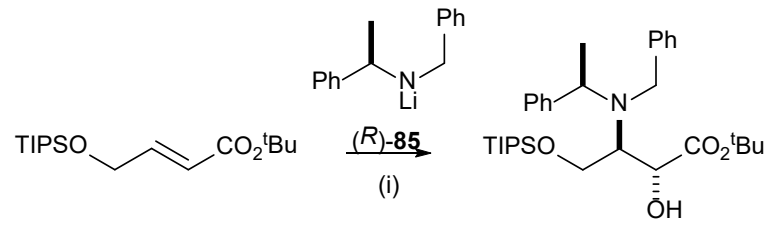

84, $>99: 1 \mathrm{dr}[(E):(Z)]$

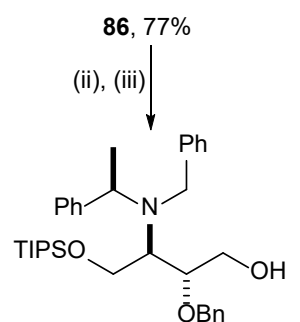

88, not isolated

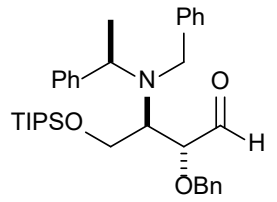

$65: 35$

[89:90] $(\mathrm{V})$<smiles>CC(NCc1ccccc1)c1ccccc1</smiles><smiles>CCOC(=O)C[C@H](O)[C@H](C)[C@H](COc1ccccc1)N(C)Cc1ccccc1</smiles>

ŌBn

$89,39 \%$

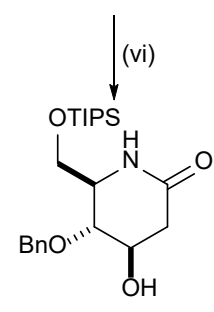

91, not isolated

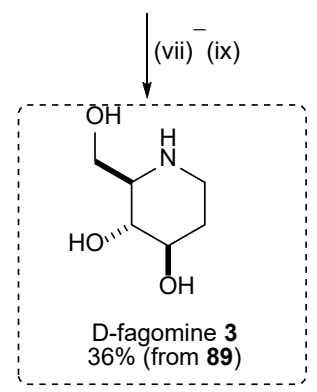

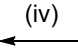

(iv)

$$
87
$$

$87 \%$ (from 86)<smiles>CCOC(=O)CC(O)C(O)C(COc1ccccc1)N(Cc1ccccc1)C(C)c1ccccc1</smiles>

$90,33 \%$

(vi)

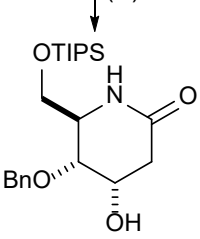

92, not isolated

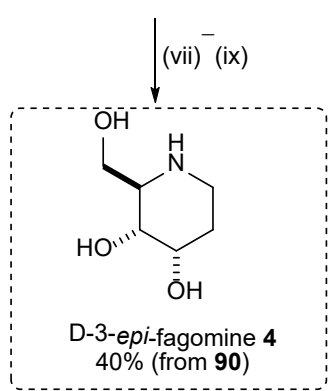

Scheme 13. Reagents and conditions: (i) (R)-85, THF, $-78{ }^{\circ} \mathrm{C}, 2 \mathrm{~h}$ then $(-)-\mathrm{CSO},-78^{\circ} \mathrm{C}$ to $\mathrm{rt}, 18 \mathrm{~h}$; (ii) $\mathrm{NaH}, \mathrm{THF}, \mathrm{BnBr}, 0^{\circ} \mathrm{C}$ to rt, $18 \mathrm{~h}$; (iii) DIBAL-H, $\mathrm{CH}_{2} \mathrm{Cl}_{2},-78^{\circ} \mathrm{C}$ to rt, $2 \mathrm{~h}$; (iv) $(\mathrm{COCl})_{2}$, DMSO, $\mathrm{Et}_{3} \mathrm{~N}, \mathrm{CH}_{2} \mathrm{Cl}_{2},-78{ }^{\circ} \mathrm{C}, 1 \mathrm{~h}$; (v) LDA, EtOAc, THF, -78 ${ }^{\circ} \mathrm{C}$ to $0{ }^{\circ} \mathrm{C}, 3 \mathrm{~h}$; (vi) $\mathrm{H}_{2}, \mathrm{Pd}(\mathrm{OH})_{2} / \mathrm{C}, \mathrm{MeOH}$, rt, $24 \mathrm{~h}$; (vii) Na, DME, naphthalene, $-78{ }^{\circ} \mathrm{C}$ to rt, $18 \mathrm{~h}$; (viii) $\mathrm{H}_{3} \mathrm{~B} \cdot \mathrm{SMe}_{2}$, THF, rt, 2.5 h then $\mathrm{H}_{2} \mathrm{O}_{2}, \mathrm{NaOH}, 85^{\circ} \mathrm{C}, 1 \mathrm{~h}$; (ix) $6 \mathrm{~N}$ aq HCl, rt, $18 \mathrm{~h}$.

The remaining two D-configured diastereoismers were synthesised upon elaboration of the epimeric precursor 94, which was prepared by epimerisation of 86. anti- $\alpha$-Hydroxy- $\beta$-amino ester 86 was oxidised under Swern condition to give the corresponding ketone $\mathbf{9 3}$ and diastereoselective reduction of 93 with $\mathrm{NaBH}_{4}$ gave the corresponding syn- $\alpha$-hydroxy- $\beta$-amino ester 94 in $55 \%$ yield as a single diastereosiomer. Subsequent Swern oxidation of $\mathbf{9 4}$ followed by aldol reaction gave a $46: 54$ mixture of 96 and 97 in $72 \%$ combined yield. Global N-deprotections via hydrogenolysis followed by in situ cyclisation and treatment 
with $\mathrm{Na}$ and naphthalene in DME gave 98 in 31\% yield and 99 in 35\% yield, respectively. Analogous elaboration of 98 and 99 gave D-4-epi-fagomine $5\left\{[\alpha]_{\mathrm{D}}{ }^{25}+13.9\left(\right.\right.$ c 1.0 in $\left.\left.\mathrm{H}_{2} \mathrm{O}\right)\right\}$ and D-5-epi-fagomine 6 $\left\{[\alpha]_{\mathrm{D}}^{25}+8.0\left(c 1.0\right.\right.$ in $\left.\left.\mathrm{H}_{2} \mathrm{O}\right)\right\}$, respectively (Scheme 14).<smiles>CCOC(=O)[C@H](O)C(CO[R](F)(F)F)N(Cc1ccccc1)C(C)c1ccccc1</smiles>

86<smiles>CC(c1ccccc1)N(Cc1ccccc1)C(CO)C(CO)OC(C)(C)C</smiles>

95, 95\%<smiles>CCOC(=O)C(CO[In]C(C)(C)C)N(Cc1ccccc1)C(C)c1ccccc1</smiles>

93, not isolated<smiles></smiles><smiles>CCCOC(=O)C(O)C(COP(=O)(F)c1ccccc1)N(Cc1ccccc1)C(C)c1ccccc1</smiles>

$94,55 \%$

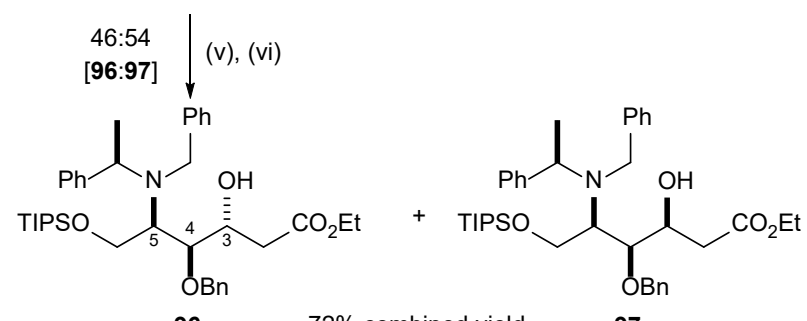

96

(vii), (viii)<smiles>O=C1CC(O)C(O)C(CO[SnH3])N1</smiles>

98, $31 \%$

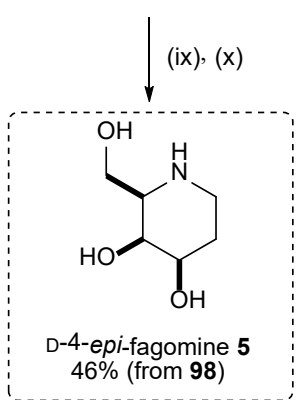<smiles>O=C1C[C@@H](O)[C@H](O)[C@H](CO)N1</smiles>

99, $35 \%$

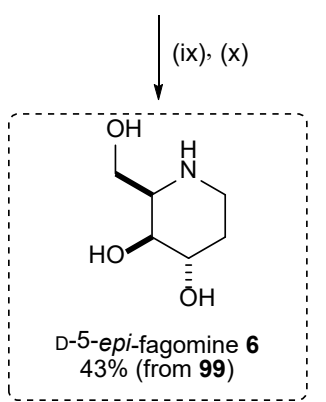

Scheme 14. Reagents and conditions: (i) $(\mathrm{COCl})_{2}$, DMSO, $\mathrm{Et}_{3} \mathrm{~N}, \mathrm{CH}_{2} \mathrm{Cl}_{2},-78^{\circ} \mathrm{C}, 1 \mathrm{~h}$; (ii) $\mathrm{NaBH}_{4}, \mathrm{MeOH},-20{ }^{\circ} \mathrm{C}, 2 \mathrm{~h}$; (iii) $\mathrm{NaH}$, THF, BnBr, $0{ }^{\circ} \mathrm{C}$ to rt, $18 \mathrm{~h}$; (iv) DIBAL-H, $\mathrm{CH}_{2} \mathrm{Cl}_{2},-78^{\circ} \mathrm{C}$ to rt, $2 \mathrm{~h}$; (v) $(\mathrm{COCl})_{2}, \mathrm{DMSO}, \mathrm{Et}_{3} \mathrm{~N}, \mathrm{CH}_{2} \mathrm{Cl}_{2},-78{ }^{\circ} \mathrm{C}, 1 \mathrm{~h}$; (vi) $\mathrm{LDA}^{\circ}$, EtOAc, THF, $-78{ }^{\circ} \mathrm{C}$ to $0{ }^{\circ} \mathrm{C}, 3 \mathrm{~h}$; (vii) $\mathrm{H}_{2}, \mathrm{Pd}(\mathrm{OH})_{2} / \mathrm{C}, \mathrm{MeOH}, \mathrm{rt}, 24 \mathrm{~h}$; (viii) $\mathrm{Na}$, DME, naphthalene, $-78{ }^{\circ} \mathrm{C}$ to rt, $18 \mathrm{~h}$; (ix) $\mathrm{H}_{3} \mathrm{~B} \cdot \mathrm{SMe}_{2}$, THF, rt, $2.5 \mathrm{~h}$ then $\mathrm{H}_{2} \mathrm{O}_{2}, \mathrm{NaOH}, 85^{\circ} \mathrm{C}, 1 \mathrm{~h}$; (x) $6 \mathrm{~N}$ aq HCl, rt, $18 \mathrm{~h}$.

\section{Conclusion}

In conclusion, D-fagomine (1,2,5-trideoxy-1,5-imino-D-arabino-hexitol) and its stereoisomers have attracted interest from the biomedical and synthetic communities due to their potent biological activities, despite their relatively simple structures. In this review, the representative methods to access this family of molecules in 
enantiopure form were presented, with a range of enantio- and/or diastereoselective synthetic strategies, which enable access to all 8 members of this class of hydroxylated piperidines.

\section{References and notes}

${ }^{1}$ (a) Magalhaes, A. F.; Santos, C. C.; Magalhaes, E. G.; Noguiera, M. A. Phytochem. Anal. 2002, 13, 215. (b) Watson, A. A.; Fleet, G. W. J; Asano, N.; Molyneux, R. J.; Nash, R. J. Phytochemistry 2001, 56, 265. (c) Iminosugars: From synthesis to therapeutic applications. Compain, P.; Martin, O. R. John Wiley \& Sons, Chichester, 2008.

2 (a) Murao, S.; Miyata, S. Agric. Biol. Chem. 1980, 44, 219. (b) Asano, N.; Tomioka, E.; Kizu, H.; Matsui, K. Carbohydrate Res. 1994, 253, 235. (c) Asano, N.; Oseki, K.; Tomioka, E.; Kizu, H.; Matsui, K. Carbohydrate Res. 1994, 259, 243. (d) Asano, N.; Yamashita, T.; Yasuda, K.; Ikeda, K.; Kizu, H.; Kameda, Y.; Kato, A.; Nash, R. J.; Lee, H. S.; Ryu, K. S. J. Agric. Food Chem. 2001, 49, 4208. (e) Yamashita, T.; Yasuda, K.; Kizu, H.; Kameda, Y.; Watson, A. A.; Nash, R. J.; Fleet, G. W. J.; Asano, N. J. Nat. Prod. 2002, 65, 1875. (f) Asano, N.; Yamauchi, T.; Kagamifuchi, K.; Shimizu, N.; Takahashi, S.; Takatsuka, H.; Ikeda, K.; Chuakul, W.; Kettawan, A.; Okamoto, T. J. Nat. Prod. 2005, 68, 1238.

${ }^{3}$ For selected reviews, see: (a) Gao, K.; Zheng, C.; Wang, T.; Zhao, H.; Wang, J.; Wangm Z.; Zhai, X.; Jia, Z.; Chen, J.; Zhou, Y.; Wang, W. Molecules 2016, 21, 1600. (b) Li, Q.; Ye, X.-S. Isr. J. Chem. 2015, 55, 336. (c) Hughes, A. B.; Rudge, A. J. Nat. Prod. Rep. 1994, 11, 135.

${ }^{4}$ Koyama, M. Agric. Biol. Chem. 1974, 38, 1111.

${ }^{5}$ Fleet, G. W.; Smith, P. W. Tetrahedron Lett. 1985, 26, 1469.

${ }^{6}$ Molyneux, R. J.; Benson, M.; Wong, R. Y.: Tropea, J. E.; Eibein, A. D. J. Nat. Prod. 1988, 51, 1198.

${ }^{7}$ Kato, A.; Hirokami, Y.; Kinami, K.; Tsuji, Y.; Miyawaki, S.; Adachi, I.; Hollinshead, J.; Nash, R. J.; Kiappes, J. L.; Zitzmann, N.; Cha, J. K.; Molyneux, R. J.; Fleet, G. W. J.; Asano, N. Phytochemistry 2015, 111, 124.

${ }^{8}$ Molyneux, R. J.; Pan, Y. T.; Tropea, J. E.; Elbein, A. D.; Lawyer, C. H.; Hughes, D. J.; Fleet, G. W. J. J. Nat. Prod. 1993, 56, 1356.

${ }^{9}$ Evans, S. V.; Hayman, A. R.; Fellows, L. E.; Shing, T. K. M.; Derome, A. E.; Fleet, G. W. J. Tetrahedron Lett. 1985, $26,1465$.

${ }^{10}$ Asano, N.; Kato, A.; Miyauchi, M.; Kizu, H.; Tomimori, T.; matsui, K.; Nash, R. J.; Molyneux, R. J. Eur. J. Biochem. 1997, 296.

${ }^{11}$ Yasuda, K.; Kizu, H.; Yamashita, T.; Kameda, Y.; Kato, A.; Nash, R. J.; Fleet, G. W. J.; Molyneux, R. J.; Asano, N. J. Nat. Prod. 2002, 65, 202.

${ }^{12}$ Lin, J.; Wang, Y.; He, X. Am. Chem. Sci. J. 2016, 14, 1.

${ }^{13}$ Han, T.; Wang, W.; Cao, X. Sep. Sci. plus 2018, 1, 520.

${ }^{14}$ For another report of the isolation of D-3-epi-fagomine $\mathbf{4}$ from the African medicinal tree Baphia nitida., see: Kato, A.; Kato, N.; Miyauchi, S.; Minoshima, Y.; Adachi, I.; Ikeda, K.; Asano, N.; Watson, A. A.; Nash, R. J. Phytochemistry 2008, 69, 1261.

${ }^{15}$ For example, see: Kundu, P.K.; Ghosh, S. K. Tetrahedron: Asymmetry 2011, 22, 1090.

${ }^{16}$ Kato, A.; Asano, N.; Kizu, H.; Matsui, K.; Watson, A. A.; Nash, R. J. J. Nat. Prod. 1997, 60, 312.

17 van den Berg, R. J. B. H. N.; Wennekes, T.; Ghisaidoobe, A.; Donker-Koopman, W. E.; Strijland, A.; Boot, R. G.; van der Marel, G. A.; Aerts, J. M. F. G.; Overkleeft, H. S. ACS Med. Chem. Lett. 2011, 2, 519.

${ }^{18}$ Ajish Kumar, K. S.; Rathee, J. S.; Subramanian, M.; Chattopadhyay, S. J. Org. Chem. 2013, 78, 7406. 
${ }^{19}$ Schofield, A. M.; Fellows, L. E.; Nash, R. J.; Fleet, G. W. J. Life Sci. 1986, 39, 645.

${ }^{20}$ Nojima, H.; Kmura, I.; Chen, F.-J.; Sugiura, Y.; Haruno, M.; Kato, A.; Asano, N. J. Nat. Prod. 1998, $61,397$.

${ }^{21}$ Taniguchi, S.; Asano, N.; Tomino, F.; Miwa, I. Horm. Metab. Res. 1998, 30, 679.

${ }^{22}$ Fleet, G. W. J.; Fellows, L. E.; Smith, P. W. Tetrahedron 1987, 43, 979.

${ }^{23}$ Fleet, G. W. J.; Witty, D. R. Tetrahedron: Asymmetry 1990, 1, 119.

${ }^{24}$ This reaction proceeded with partial $\mathrm{N}$-Cbz removal. The crude reaction mixture was treated with $\mathrm{CbzCl}$.

${ }^{25}$ Désiré, J.; Dransfield, P. J.; Gore, P. M.; Shipman, M. Synlett 2001, 1329.

${ }^{26}$ Squarcia, A.; Vivolo, F.; Weinig, H.-G.; Passacantilli, P.; Piancatelli, G. Tetrahedron Lett. 2002, 43, 4653.

${ }^{27}$ Jiang, F.-X.; Liu, Q.-Z.; Zhao, D.; Luo, C.-T.; Guo, C.-P.; Ye, W.-C.; Luo, C.; Chen, H. Eur. J. Med. Chem. $2014,77,211$.

${ }^{28}$ Kumari, N.; Reddy, B. G.; Vankar, Y. D. Eur. J. Org. Chem. 2009, 160.

${ }^{29}$ Kallam, S. R.; Datrika, R.; Khobare, S. R.; Gajare, V. S.; Rajana, N.; Mohan, H. R.; Babu, J. M.; Siddaiah, V.; Pratap, T. V. Tetrahedron Lett. 2016, 57, 1351.

${ }^{30}$ Das, P.; Ajay, S.; Shaw, A. K. Synthesis 2016, 3753.

${ }^{31}$ Viuff, A. H.; Jensen, H. H. Org. Biomol. Chem. 2016, 14, 8545.

32 Díez, J. A.; Gálvez, J. A.; Díaz-de-Villegas, M. D.; Badorrey, R.; Bartholomew, B.; Nash, R. J. Org. Biomol. Chem. 2012, 10, 9278.

${ }^{33}$ Corkran, H. M.; Munneke, S.; Dangerfield, E. M.; Stocker, B. L.; Timmer, M. S. M. J. Org. Chem. 2013, $78,9791$.

${ }^{34}$ Banba, Y.; Abe, C.; Nemoto, H.; Kato, A.; Adachi, I.; Takahata, H. Tetrahedron: Asymmetry 2001, $12,817$.

35 Takahata, H.; Banba, Y.; Sasatani, M.; Nemoto, H.; Kato, A.; Adachi, I. Tetrahedron 2004, 60, 8199.

${ }^{36}$ Takahata, H.; Banba, Y.; Ouchi, H.; Nemoto, H.; Kato, A.; Adachi, I. J. Org. Chem. 2003, 68, 3603.

${ }^{37}$ Kim, J.-Y.;Mu, Y.; Jin, X.; Park, S.-H.; Pham, V.-T.; Song, D.-K.; Lee, K.-Y.; Ham, W.-H. Tetrahedron $2011,67,9426$.

${ }^{38}$ Bartali, L.; Scarpi, D.; Guarna, A.; Prandi, C.; Occhiato E. G. Synlett 2009, 913.

${ }^{39}$ Occhiato, E. G.; Scarpi, D.; Guarna, A. Eur. J. Org. Chem. 2008, 524.

${ }^{40}$ Bartali, L.; Casini, A.; Guarna, A.; Occhiato, E. G.; Scarpi, D. Eur. J. Org. Chem. 2010, 5831.

${ }^{41}$ Kato, A.; Miyauchi, S.; Kato, N.; Nash, R. J.; Yoshimura, Y.; Nakagome, I.; Hirono, S.; Takahata, H.; Adachi, I. Bioorg. Med. Chem. 2011, 19, 3558 .

${ }^{42}$ Babich, L.; van Hemert, L. J. C.; Bury, A.; Hartog, A. F.; Falcicchio, P.; van der Oost, J.; van Herk, T.; Wever, R.; Rutjes, P. J. T. Green Chem. 2011, 13, 2895.

${ }^{43}$ (a) von der Osten, C. H.; Sinskey, A. J.; Barbas, III, C. F.; Pederson, R. L.; Wang, Y.-F.; Wong, C.-H. J. Am. Chem. Soc. 1989, 111, 3924. (b) Oroz-Guinea, I.; Hernández, K.; Bres, F. C.; Guérard-Hélaine, C.; Lemaire, M.; Clapés, P.;García-Junceda E. Adv. Synth. Catal. 2015, 357, 1951. (c) Wei, M.; Li, Z.; Li, T.; Wu, B.; Liu, Y.; Qu, J.; Li, X.; Li, L.; Cai, L.; Wang, P. G. ACS Catal. 2015, 5, 4060. (d) Sugiyama, M.; hong, Z.; Liang, P.-H.; Dean, S. M.; Whalen, L. J.; Greenberg, W. A.; Wong, C.-H. J. Am. Chem. Soc. 2007, 129, 14811. (e) Castillo, J. A.; Calveras, J.; Casas, J.; Mitjans, M.; Vinardell, M. P.; Parella, T.; Inoue, T.; Sprenger, G. A.; Joglar, J.; Clapés, P. Org. Lett. 2006, 8, 6067.

${ }^{44}$ Marjanovic, J.; Ferjancic, Z.; Saicic, R. N. Tetrahedron 2015, 71, 6784.

${ }^{45}$ Yokoyama, H.; Ejiri, H.; Miyazawa, M.; Yamaguchi, S.; Hirai, Y. Tetrahedron: Asymmetry 2007, $18,852$. 
${ }^{46}$ Bates, R. W.; Ng, P. S. Tetrahedron Lett. 2011, 52, 2969.

${ }^{47}$ Searles, S.; Li, Y.; Nassim, B.; Lopes, M.-T.; Tran, P. T.; Crabbé, P. J. Chem. Soc., Perkin Trans. $11984,747$.

${ }^{48}$ Kundu, P. K.; Ghosh, S. K. Org. Biomol. Chem. 2009, 7, 4611.

${ }^{49}$ Csatayová, K.; Davies, S. G.; Fletcher, A. M.; Ford, J. G.; Klauber, D. J.; Roberts, P. M.; Thomson, J. E. Tetrahedron 2015, 71, 7170 .

${ }^{50}$ Csatayová, K.; Davies, S. G.; Fletcher, A. M.; Ford, J. G.; Klauber, D. J.; Roberts, P. M.; Thomson, J. E. J. Org. Chem. 2014, $79,10932$.

${ }^{51}$ (a) Bond, C. W.; Cresswell, A. J.; Davies, S. G.; Fletcher, A. M.; Kurosawa, W.; Lee, J. A.; Roberts, P. M.; Russell, A. J.; Smith, A. D.; Thomson, J. E. J. Org. Chem. 2009, 74, 6735. (b) Davies, S. G.; Fletcher, A. M.; Kurosawa, W.; Lee, J. A.; Poce, G.; Roberts, P. M.; Thomson, J. E.; Williamson, D. M. J. Org. Chem. 2010, 75, 7745. (c) Bagal, S. K.; Davies, S. G.; Fletcher, A. M.; Lee, J. A.; Roberts, P. M.; Scott, P. M.; Thomson, J. E. Tetrahedron Lett. 2011, 52, 2216. (d) Csatayová, K.; Davies, S. G.; Ford, J. G.; Lee, J. A.; Roberts, P. M.; Thomson, J. E. J. Org. Chem. 2013, 78, 12397. (e) Brambilla, M.; Davies, S. G.; Fletcher, A. M.; Roberts, P. M.; Thomson, J. E. Tetrahedron 2014, 70, 204. (f) Davies, S. G.; Fletcher, A. M.; Thomson, J. E. Org. Biomol. Chem. 2014, 12, 4544 .

${ }^{52}$ Davies, S. G.; Fletcher, A. M.; Kennedy, M. S.; Roberts, P. M.; Thomson, J. E. Tetrahedron 2018, $74,7261$. 